\title{
THE IMPACT OF TRAINED VOLUNTEER MEALTIME ASSISTANTS ON DIETARY INTAKE AND SATISFACTION WITH MEALTIME CARE IN ADULT HOSPITAL INPATIENTS: A SYSTEMATIC REVIEW
}

\author{
Fiona F A Howson ${ }^{1-3}$ \\ Avan Aihie Sayer ${ }^{1-6}$ \\ Helen C Roberts ${ }^{1-4}$
}

1. Academic Geriatric Medicine, University of Southampton

2. NIHR CLAHRC: Wessex

3. University Hospitals Southampton Foundation Trust

4. MRC Lifecourse Epidemiology Unit, University of Southampton

5. Ageing Geriatrics \& Epidemiology, Institute of Neuroscience and Institute for Ageing, Newcastle University

6. NIHR Newcastle Biomedical Research Centre in Ageing and Chronic Disease, Newcastle University and Newcastle upon Tyne NHS Foundation Trust 


\section{Abstract}

Background

Malnutrition is common in hospital inpatients and is associated with increased morbidity and mortality. Insufficient assistance at mealtimes can contribute to this and therefore trained volunteer mealtime assistants may be of benefit.

Objectives

To identify and review the current evidence for the impact of trained volunteer mealtime assistants on dietary intake and satisfaction with mealtime care in adult hospital inpatients. Methods

A systematic search of Medline, Embase and CINAHL was conducted to identify relevant articles. Articles of any methodology were considered. Quality assessment and data extraction were carried out by two reviewers independently.

Participants

Participants were inpatients in a hospital setting, including rehabilitation units. Participants in long term care facilities were excluded.

Intervention

Articles that examined the effect of trained volunteer mealtime assistants on nutritional outcomes or satisfaction with mealtime care were included.

Results

5576 articles were identified, of which 14 were included in the review. Nine were small research studies and five were quality improvement initiatives. The quality of eight studies was moderate, with one study being of lower quality. Eight articles reported dietary intake and seven demonstrated an improvement, with protein intakes at volunteer mealtimes increasing by $4.3 \mathrm{~g}-10.1 \mathrm{~g}$ and energy intakes by $44-105 \mathrm{kcal}$. Ten articles reported positive staff, patient and volunteer feedback. No adverse events were reported.

Conclusion

There is evidence from small studies and improvement projects that trained volunteer mealtime assistants are safe and improve satisfaction with mealtime care in hospital inpatients, although evidence for an effect on dietary intake was less consistent. Larger studies with robust methodology are required to confirm this.

Key Words

Volunteer - mealtime assistant - dietary intake - mealtime care - older people

\section{Background}

Malnutrition is common among hospital inpatients: in 2011,25\% of hospital inpatients in the UK were recognised to be at risk of malnutrition using the Malnutrition Universal Screening Tool (MUST)[1], a tool which incorporates body mass index (BMI), unplanned weight loss and nutritional intake to produce a score that categorises patients' risk of malnutrition[2]. The prevalence of malnutrition was greater in patients admitted to Medicine for Older People wards, at 34\%[1]. A similar picture is seen globally, with one multinational study reporting the prevalence of malnutrition (using the Mini Nutritional Assessment) as 38.7\% in hospital inpatients aged over 65 years[3].

The negative health consequences of malnutrition are well documented. A malnourished person is more likely to visit their General Practitioner (GP) and be admitted to hospital[4], where they have a longer stay [5-7], a higher rate of complications [5, 6, 8], and a slower functional recovery $[7,9,10]$. There is also an increased risk of hospital readmission[10,11] and mortality[12-14]. In 2011-12, malnutrition was estimated to cost the UK $£ 19.6$ billion[15].

Interventions to treat malnutrition commonly focus on dietary supplementation. Oral nutritional supplements can lead to weight gain and may reduce complications and mortality in older people at risk of malnutrition[16]. Individualised dietetic assessment and treatment can improve protein and energy intake[17-19], and may lead to reductions in mortality[20], 
complications[19] and re-admissions to hospital[19]. Fortification of hospital food has also proved successful in increasing protein and energy intakes[21-23].

However, other important factors contribute to malnutrition in hospital inpatients. Physical barriers, such as food being placed out of reach, packages not being opened and insufficient feeding assistance have all been reported[24-27]. Older inpatients are disproportionately affected, as they are more likely to require mealtime assistance[25-27]. Competing clinical priorities (such as medication rounds) and the timing of staff meal breaks have been cited as exacerbating the problem[28, 29].

Interventions to address these problems have been investigated. The use of coloured meal trays to identify patients who need assistance or encouragement has been reported[30], but there is no evidence examining their impact on clinical outcomes. Studies of protected mealtimes, where all non-urgent activity ceases, have failed to demonstrate any impact on nutritional intake[31-33]. Mealtime assistants are trained staff or volunteers who provide additional mealtime support (such as cleaning patients' tables, positioning meal trays, opening packaging, cutting up food, and feeding patients).

We first considered the evidence for the use of trained volunteer mealtime assistants in a systematic review published in 2011[34]. Both hospital inpatients and long term care residents were included, and there was some evidence that volunteers improved mealtime care, although the findings were limited by the poor methodological design of the studies available. More recently, Tassone et al conducted a systematic review and meta-analysis of the effect of additional mealtime assistance (provided by staff or volunteers) in older hospital inpatients[35]. The meta-analysis found evidence of improved protein and energy intakes with additional assistance. However, most participants had been assisted by paid staff rather than volunteers (738 participants compared with 32), and so this cannot be assumed to demonstrate an effect of volunteer assistance specifically.

The current review was therefore designed to provide an update of the evidence examining the impact of trained volunteer mealtime assistants, on both dietary intake and quality of mealtime care, focusing on adult hospital inpatients.

\section{Methods}

The review was carried out in accordance with the Preferred Reporting Items for Systematic Reviews and Meta-Analyses (PRISMA) guidelines[36]. It was prospectively registered with PROSPERO (registration ID CRD42016035419). Identification of Articles

A systematic search was carried out in Medline, EMBASE and CINAHL to identify articles relating to the use of mealtime volunteers helping hospital inpatients. The search strategy used a combination of Medical Subject Headings (MeSH) and key words (Appendix 1). No limitations in publication date or language were applied. The final database search was performed in August 2015. The reference lists of all included articles and any relevant reviews identified by the search were examined to identify any additional articles.

\section{Criteria for inclusion}

Scoping searches identified a paucity of literature on this subject and therefore broad inclusion criteria were applied in order to identify as many relevant articles as possible. Inclusion criteria are shown in Table 1 . There was no restriction on study design. Selection of Studies

Titles and abstracts were screened independently by two reviewers, and the full text of any article that potentially met the inclusion criteria was retrieved and reviewed. Both reviewers independently determined eligibility and resolved any disagreements by discussion. Trials with multiple publications were identified and the most complete version was included in the review. Data extraction

Data were extracted by each reviewer independently using a standardised template designed by the authors for this review. The template was piloted on a sample of articles identified in scoping searches and refined before use in the review. 
The data extracted from each article comprised: study design and setting, participant inclusion and exclusion criteria, volunteer recruitment, training and role, details of participants and control group, outcomes measures and how assessed, study findings, subgroup analyses, statistical analyses and adverse event reporting.

Quality assessment

The quality of each research study was assessed using a checklist designed for randomised and non-randomised studies[37], as recommended by the Centre for Reviews and Dissemination at the University of York[38]. The checklist consists of 27 items, and includes within it assessment of risk of bias at a study level. Risk of bias at an outcome level was not formally assessed, but was discussed within the narrative of the results. Assessment was performed by each reviewer independently and differences resolved by discussion. Quality assessment was not performed on reports of quality improvement projects.

Data Synthesis

The heterogeneity of study design and outcome measures meant that a formal meta-analysis was not feasible. A narrative synthesis was therefore undertaken.

\section{Results}

\section{Search Results}

5576 results were identified through the database searches (Figure 1). Following removal of duplicates, 3478 titles were reviewed, with 38 articles identified as potentially relevant to the review. After full text review, 20 articles met the inclusion criteria of the review, of which 6 were multiple reports of the same study. 14 original articles were therefore included in the review process.

Quality of Articles

Of the nine research studies, eight studies were of moderate quality, scoring 15-20 points from an available total of 31 . One study was of lower quality and scored 12 points. Of the seven points available in the risk of bias section, seven studies received 4 points and two studies received 5 points.

Overview of Articles

The characteristics of the 14 articles are summarised in Table 2. Publication date ranged from 2002 to 2015, with eight published within the last 5 years[32, 39-45]. The setting in thirteen articles was an acute hospital[32, 39-50], with the remaining study set in a short stay dementia assessment unit[51]. The UK was the most common location (7 articles)[39, 41, 44-47, 50], followed by Australia ( 4 articles) [32, 42, 43, 49], the United States ( 2 articles) [40, 48] and New Zealand (1 article)[51].

Of the 14 articles, eight reported research studies of varying quasi experimental design[32, $42-44,48-51]$. One article defined itself as both a study and a programme evaluation, but was considered a study in this review due to the scientific nature of the published report[40]. Of the nine research studies, six had received standard research ethics approval[42-44, 49-51], one was exempted by the local ethics board[32] and two did not make reference to the ethical approvals process [40,48]. Four articles were descriptions of service or quality improvement projects[39, 45-47]. One article was a research letter and was considered a quality improvement project for the purposes of this review due to the limited information available[41].

Population

The number of participants included in nine of the articles varied widely from 8 to 3911[32, 41-44, 48-51]; one study and four quality improvement projects did not report the number of patients[39, 40, 45-47]. In six studies, patients requiring mealtime assistance were specifically identified and recruited, with participant numbers ranging from 8-68[42, 43, 48-51]. In two studies, all patients on study wards were included, regardless of a pre-defined need for assistance, and greater numbers of participants were included $(1012$ and 3911)[32, 44]. In one project report it was not clear how participants were selected[41].

The patient population was older hospital inpatients in the majority of studies and projects: five took place in wards where only older people were admitted[40, 42, 44, 47, 49], two studies 
recruited patients aged over 65 years[48,50], three studies had a mean participant age over 75 years [41, 43, 51], and one project described its population as "frail older patients"[46]. The remaining study had a participant population with a mean age of 65 years[32] and the other two projects did not describe the age of their patient population $[39,45]$.

Eight studies and one report included a control group [32, 41-44, 48-51]. In four studies, the control group was the same patients on days when volunteers were not present $[42,43,49,51]$. Huxtable and Palmer used a demographically similar cohort from the study ward prior to the intervention as their control group[32]. Robinson et al used a control group that was matched to the participants in respect of age and the amount of assistance required[48]. Wright et al used a historical control group, although this group differed in the amount of feeding assistance required and the type of modified diet prescribed[50]. Roberts et al used a cohort of patients from the study ward prior to intervention as well as a cohort of patients from a parallel ward as a contemporaneous control[44]. Gilbert et al used patients on the study wards receiving usual care as their control, although the similarity of this group to the participants was not reported[41]. Intervention

The number of volunteers trained to provide mealtime assistance was reported in nine articles[39, 41, 42, 44-46, 48-50], and ranged from 3 to 95. Volunteers were commonly local students: two studies exclusively recruited students $[41,50]$ and four more reported that students were a prominent component of their volunteer workforce[40, 45, 46, 48].

The training programme for volunteers was described in seven articles[40, 43-46, 48, 50]. The most common method, described in three studies[40,43,44] and one project[46], was a training session followed by a practical observation session. A three hour training session was reported in a further two articles[45, 48]. Wright et al described a week long training programme for their volunteers [50]. Training was led by speech and language therapists and dieticians in six hospitals[41, 42, 44-46, 50], and by nurses in four hospitals[32, 40, 47, 48]. Four articles made no reference to who provided volunteers' training[39, 43, 49, 51].

In twelve of the fourteen articles[32, 40-49,51], the role of the volunteer included all forms of mealtime assistance, such as preparing the meal area, re-arranging meal trays, assisting with packaging, cutting up food and feeding. Wright et al described an extended role, where volunteers were present for 8 hours a day, 3 days a week[50]. As well as providing mealtime assistance, the volunteers helped with menu choices, and distributed and encouraged snacks and nutritional supplements. In the remaining project report, volunteers assisted with pre meal preparation and socialisation at mealtimes but did not feed patients[39].

The introduction of trained mealtime volunteers was the sole intervention in 9 articles[39$45,48,49]$. A variety of co-interventions were reported in the remaining five. The main focus of two studies was the implementation of a protected mealtimes programme, with additional assistance by volunteers incorporated into this programme[32, 47]. In addition to implementing protected mealtimes, Murray and colleagues also made additional snacks available to all patients[47]. Brown \& Jones combined the introduction of volunteers with a renewed focus on nutritional care, holding a "Good Nutrition Awareness Week", updating nutrition screening tools and implementing new care pathways and dietetic referral forms[46]. An individualised eating and drinking plan was part of the intervention in one study[50]. Wong et al examined 3 different mealtime interventions in their study, although each was investigated in isolation with a washout period between the introduction of the next intervention[51].

\section{Outcomes}

Dietary Intake

The most common outcome measured was dietary intake, reported in eight of the research studies and one project. Six calculated protein and energy intake[32, 42, 43, 49-51] and two reported the proportion of a meal consumed[41, 48]. Both these articles reported a significant increase in consumption when volunteers were present. Robinson et al reported $59 \%$ of the meal was consumed when volunteers were assisting, compared to $32 \%$ when they were not $(\mathrm{p}<0.001)[48]$. Gilbert et al did not present the raw data, but stated that food intake was significantly better $(\mathrm{p}<0.01)$ in those assisted by volunteers[41]. 
The six studies that calculated protein and energy intake used a variety of methods. Two studies weighed food waste[43, 49], three studies used researchers' visual estimates of plate waste[32, 42, 51] and the remaining study used food record charts completed by the volunteers[50]. All used the known nutritional content of the meal to determine the protein and energy consumed. The results of these six studies are shown in Table 3.

Walton et al measured dietary intake in the same participants with and without volunteer assistance and found that protein intake significantly increased: by $10.1 \mathrm{~g}$ at volunteer mealtimes $(p=0.015)$ and 10.7g over the course of 24 hours $(p=0.015)$ [49]. Mealtime energy intake also improved by $105 \mathrm{kcal}(\mathrm{p}=0.072)$, although there was no significant increase over 24 hours.

Manning et al used similar methodology, and also reported significant increases in mealtime protein $(4.3 \mathrm{~g}, \mathrm{p}=0.009)$, daytime protein $(8.7 \mathrm{~g}, \mathrm{p}=0.004)$ and mealtime energy intake (95kcal, $p=0.005$ )[43]. Again, there was no significant increase in energy intake over 24 hours.

Wong et al measured the energy intake of participants before the introduction of volunteers, whilst volunteers were present and after the intervention had finished[51]. Mealtime energy intakes increased (by an average of $44 \mathrm{kcal}, \mathrm{p}<0.001$ ) when volunteers were present and returned to pre-volunteer levels when the intervention ceased. Protein intakes were not reported.

Wright et al measured energy and protein intake between $8 \mathrm{am}$ and $4 \mathrm{pm}$ (the rostered hours of their volunteers) and compared this to an historical control group [50]. There were significant increases of both energy and protein intake in the intervention group $(618 \mathrm{kcal}$ and $28 \mathrm{~g}, \mathrm{p}<$ 0.001 and $p=0.01$ respectively). The provision of additional snacks and nutritional supplements was part of the volunteers' role, and there was also a significant increase in the energy and protein obtained from nutritional supplements.

Huxtable \& Palmer measured dietary intake on one ward before and after the introduction of a protected mealtimes programme (which included the provision of trained volunteers)[32]. There was a statistically significant increase in protein intake (of $2 \mathrm{~g})$ at breakfast $(\mathrm{p}=0.025)$, but no difference in lunch, dinner or daytime protein intake and no difference in energy intake at individual meals or over a whole day.

Huang et al compared dietary intake in a cohort of participants on days when volunteers were and were not present, and found increases in energy and protein intakes at mealtimes and on days when volunteers were present[42]. Although there was a trend to increased protein and energy intakes, none of the increases were of statistical significance.

Satisfaction with mealtime care

Five studies formally documented opinions and feedback from patients, staff or volunteers, most commonly via a combination of questionnaires and interviews or focus groups[42-44, 48, 49]. No study described the design or validation of their questionnaire. Five project reports included informal feedback[39, 41, 45-47], although there was little discussion of how this feedback was gained in most.

Huang et al provided questionnaires to staff and volunteers, and all respondents agreed that the programme was beneficial[42]. Nurses reported that the volunteer presence gave them time to complete other nursing duties.

Manning et al administered questionnaires to staff and volunteers and conducted interviews with patients[43]. Nursing staff frequently reported lack of time to assist patients at mealtimes, whilst the majority of volunteers found they had enough time to assist. Volunteers and staff found the programme worthwhile, and patient feedback was similarly positive.

Roberts et al conducted interviews and focus groups with patients, relatives, staff and volunteers [44]. Staff again reported that having volunteers to assist at mealtimes provided them with additional support and enabled them to complete other clinical tasks. Patients were appreciative of the additional help and enjoyed the opportunity to build a relationship with the volunteers. Volunteers felt appreciated in their role and enjoyed their duties.

Robinson et al asked volunteers to complete evaluation forms, describing their thoughts and experiences[48]. Volunteers felt their role was necessary to help support the nurses, benefited the patients and was enjoyable. 
Walton et al asked volunteers and staff to complete an open-ended questionnaire, and carried out a focus group with four volunteers[49]. Staff again identified time pressures at mealtimes that were eased by the introduction of the volunteer programme. Volunteers felt that talking with patients at mealtimes had a positive impact on nutritional intake.

Four project reports included positive informal feedback from staff, volunteers and patients, reflecting many of the themes identified in the above studies[39, 45-47]. Furthermore, Gilbert et al, in their project, administered questionnaires to patients to determine their enjoyment of their meals[41]. The contents of the questionnaire and results were not reported, but patient enjoyment of meals was reported to be significantly increased when volunteers were assisting ( $\mathrm{p}<0.001)$. No study or project reported any negative feedback.

Volunteer Activity

Two studies [40,43] reported the activity of the volunteers. Buys et al analysed volunteer encounter forms and reported that volunteers completed an average of 3 tasks for each patient they saw and spent an average of 48 minutes with each patient[40]. This was equivalent to savings of \$12-26 in staff costs for each volunteer-patient encounter.

Manning et al observed mealtimes and found that volunteers were able to provide each patient with twice as much time as nursing staff, with volunteers spending an average of 12 minutes per patient, compared to 6 minutes from nursing staff[43].

\section{Other Reported Outcomes}

Huxtable \& Palmer observed mealtimes and reported that the proportion of patients being fed doubled following the introduction of protected mealtimes and volunteers[32]. There were also significant increases in the number of patients positioned appropriately prior to their meal, the number of meals placed within reach and the amount of time spent assisting at mealtimes, as well as a significant reduction in the time before patients received assistance with their meals.

Outcomes relating to nutritional status were reported in two articles[46, 51]. Wong et al measured nutritional status of participants using weight, BMI and mid-arm circumference and reported a significant increase in BMI (of 0.37, p < 0.04) following the introduction of volunteers, but no change in mid-arm circumference[51]. Brown \& Jones reported that fewer patients were at high or medium risk of malnutrition following the introduction of their intervention [46]. Adverse Events

The absence of adverse events was specifically reported in 3 articles[40, 44, 46]; in the remaining 11, adverse events were not discussed.

\section{Discussion}

This systematic review identified 14 unique articles describing the introduction of trained volunteer mealtime assistants; nine were research studies and five were quality improvement projects. The majority of studies were of moderate quality; none were of high quality.

Of the 14 articles identified, the majority had been published in the last five years and related to acute hospital care. Volunteering in hospitals is a long held tradition in many countries, and the current climate of increasing demand in healthcare systems has led to greater recognition of the value of volunteers and the development of innovative volunteer roles[52]. This, coupled with the continuing problem of malnutrition in hospital inpatients, may account for the growing interest in volunteer mealtime assistants demonstrated by this recent increase in publications.

Participant numbers varied widely in the nine articles where this was reported. Studies where mealtime assistance was targeted to a specific population had smaller participant numbers $(<100)$ than those where the intervention was targeted at all patients on the ward $(>$ 1000). Most articles focussed on older inpatients, who are more likely to experience difficulties at mealtimes and receive insufficient assistance[25].

The volunteer role was to assist with all aspects of mealtime care in most articles, although there were two notable exceptions to this. In one project, volunteers were not trained to feed patients, and simply assisted with preparation and focussed on social contact with patients during mealtimes[39]. By contrast, Wright et al described an extended role for their three volunteers: they attended a week of training and were present on the wards 8 hours a day three 
days a week[50]. This commitment of time, by both volunteers and trainers, may be difficult to sustain, and the transferability of this intensive programme into other hospitals is far from certain.

Dietary intake was measured in eight articles, but the methods used varied, making direct comparisons difficult. In two articles, volunteers estimated food intake as a proportion of the meal consumed by the intervention group, but neither described how this data was collected in the control group $[41,48]$. Visually estimating plate waste has previously been found to be comparable to weighing plate waste[53], but neither study reports if volunteers were specifically trained to estimate plate waste and how inter-observer variability was minimised. Additionally, the proportion of a meal consumed does not directly correspond to energy and protein intake. Therefore, although both studies reported significant increases in the amount eaten, these results must be interpreted with caution.

The remaining six studies reported energy and protein intake. In three, this was done by researchers visually estimating the proportion of a meal consumed and using the known nutritional content of the meal to calculate energy and protein intake[32, 42, 51]. In these three studies, inter and intra-observer variability of visual estimates was monitored and minimised by regular training of the researchers. Wright et al used food record charts completed by volunteers to calculate energy and protein intake, using an average of three days intake[50]. It is not clear whether the volunteers' ability to estimate plate waste and complete food record charts was assessed. The remaining two studies[43,49] weighed food waste and used the known weight and composition of meals to calculate energy and protein intake, a method which provides a high degree of accuracy.

These six studies had mixed results. Four studies reported an increase in protein and/or energy intake. The three studies which targeted feeding assistance to a specific cohort of patients acting as their own controls $[43,49,51]$ all reported increased energy intakes, and two reported increased protein intakes, with volunteers $[43,49]$. The greatest increases in protein and energy intakes were reported by Wright et al [50], which is unsurprising, as volunteers were present on the wards for longer and had an extended role that included provision of snacks and supplements; the significant increases in energy and protein derived from nutritional supplements is likely to be one of the main reasons for the considerable increase in dietary intake. An additional problem with this study was that the control group differed from the intervention group in terms of the assistance required and the type of modified diet they ate. Both of these factors are known to influence nutritional intake[54,55]. The control group data was collected 3 years previously, and nutritional practices in the hospital may have changed. Lastly, protein and energy intakes were measured differently in the control and intervention groups (weighed food intake versus food record charts completed by volunteers). Therefore, although substantial increases in protein and energy intake were demonstrated, several confounding factors must be considered.

Two studies found little difference when volunteers were present. For Huang et al, this may have been due to the small sample size of this study $(n=8)[42]$. Huxtable \& Palmer reported a solitary increase in protein intake at breakfast[32]. The authors did not report which mealtimes volunteers helped at, and so the significance of this finding, and its association with volunteer mealtime assistance, is uncertain.

In summary, there is some evidence from small studies that volunteers providing targeted mealtime assistance to specific patients may lead to an improved energy and protein intake.

All articles that explored the opinions of patients, staff or volunteers reported universally positive findings. Common themes that emerged included: volunteers provided support to nurses and enabled them to concentrate on other tasks, mealtimes became more enjoyable and social, volunteers enjoyed their role and saw the benefits to staff and patients, and patients appreciated the help from volunteers. Accordingly, there is consistent evidence that trained volunteer mealtime assistants are appreciated by staff and patients, and improve satisfaction with mealtime care.

The average time volunteers spent with a patient differed considerably in the two articles where it was reported (12 minutes and 48 minutes) [32, 40]. It is not obvious from the reports 
why this time should vary so widely, and no other reports provided this information to allow further comparisons. Buys et al calculated the staff costs saved by taking this average volunteerpatient encounter, and demonstrated that $\$ 12-\$ 26$ could be saved, depending on the seniority of the staff member released[40]. However, there was no discussion of the cost of establishing the volunteer programme, so no conclusion about the overall economic benefit can be drawn.

Huxtable \& Palmer reported other additional positive outcomes of their study, with more patients positioned correctly, more meals within reach, more time spent assisting patients and less time waited before assistance was given[32]. However, it is not clear whether these outcomes were attributable to the presence of volunteers on the ward, or due to improved mealtime care as a result of the wider protected mealtimes programme.

Wong et al found an improved BMI in their 7 participants[51]. However, this increase was small (0.37), with uncertain clinical significance. Brown \& Jones reported a decrease in the number of patients who were classified at high or medium risk of malnutrition[46], but this could have been due to the additional nutrition focus that was included in the project, rather than the introduction of volunteers. No firm conclusions can be drawn about the effect of volunteers on nutritional status.

No adverse events were reported in any article, demonstrating that trained volunteer mealtime assistants can safely help older patients including those who require help with feeding.

\section{Limitations}

One limitation of this review is that grey literature was not searched, meaning some relevant articles may have been omitted. However, it is likely that searching of grey literature would have identified more quality improvement projects, which frequently have uncertain methodology and outcomes, and may not have contributed further to the conclusions of this review.

No formal assessment of the risk of publication bias or selective outcome reporting was carried out. However, given that a meta-analysis was not carried out and that no definitive conclusions could be reached regarding the impact of trained volunteer mealtime assistants on dietary intake, the review's overall conclusions are unlikely to have been affected by this.

\section{Conclusions}

Malnutrition is common in older hospital inpatients, and is associated with increased morbidity and mortality. Older people in hospital do not always receive the help they need at mealtimes, which contributes to poor nutritional intake. This review investigated whether volunteers, trained to provide mealtime assistance, had any effect on dietary intake and satisfaction with mealtime care. There are few large scale studies examining this subject, but smaller studies and quality improvement projects suggest that training volunteers is feasible, safe and improves patient and staff satisfaction with mealtime care, although evidence of an effect on dietary intake is inconsistent.

Future research into trained volunteer mealtime assistants should therefore aim to initially clarify any impact of volunteers on dietary intake. These studies must have robust methodology; randomising participants to volunteer assistance or usual care may not be feasible or ethical (with volunteers having to ignore the needs of participants they had not been allocated to help), but future studies should include an appropriately matched control group (either with patients acting as their own controls, or a contemporaneous control group drawn from the same population) and a sample size determined by a power calculation. Dietary intake should be determined by weighing food waste or estimating plate waste, provided all researchers are trained in this methodology and intra and inter-observer variability is monitored and minimised. If a positive effect on dietary intake is demonstrated, investigation of the effect on clinical outcomes (such as change in weight or risk of malnutrition) is warranted. A mixed methods approach is recommended to include the views and experience of patients, volunteers and staff and an analysis of the overall costs (including freeing up staff time)of a volunteer programme. 
Table 1: Inclusion Criteria for Articles Included in the Review

\begin{tabular}{|l|l|}
\hline Population & $\begin{array}{l}\text { Adult hospital inpatients, including } \\
\text { rehabilitation units. Long term care facilities } \\
\text { were excluded. }\end{array}$ \\
\hline Intervention & $\begin{array}{l}\text { Provision of additional mealtime assistance by } \\
\text { trained volunteers. }\end{array}$ \\
\hline Comparator & $\begin{array}{l}\text { Presence of a comparator group was not a } \\
\text { requirement for inclusion in the review. } \\
\text { Articles reporting any, or no, comparator } \\
\text { group were considered. }\end{array}$ \\
\hline Outcomes & $\begin{array}{l}\text { Any nutritional outcomes, satisfaction with } \\
\text { mealtime care (including questionnaires, } \\
\text { interviews or informal reports from patients, } \\
\text { staff or volunteers) }\end{array}$ \\
\hline
\end{tabular}


Figure 1: Selection of articles for inclusion

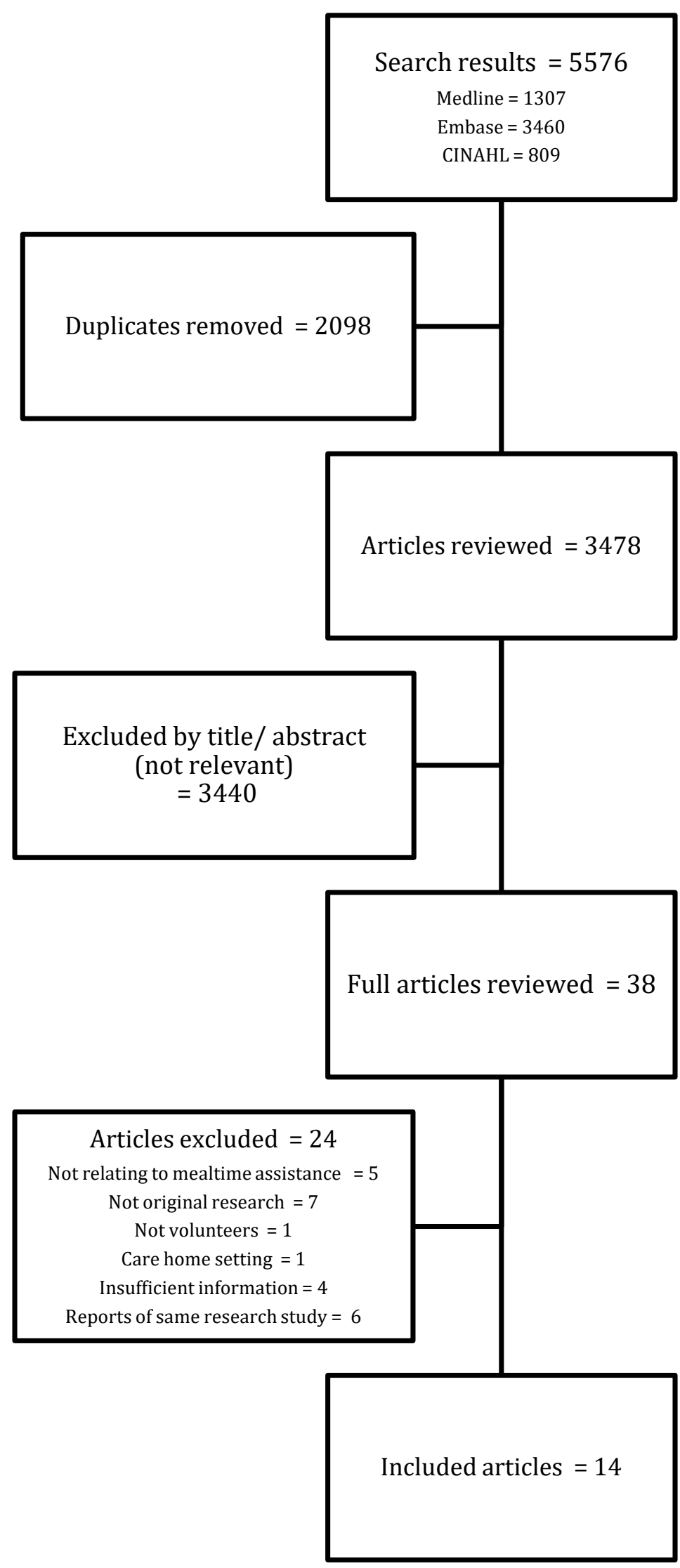


Table 2: Characteristics of Included Articles

\begin{tabular}{|c|c|c|c|c|c|c|c|c|c|}
\hline \multirow[t]{2}{*}{ Study } & \multirow[t]{2}{*}{ Design } & \multirow{2}{*}{$\begin{array}{l}\text { Population \& } \\
\text { Setting }\end{array}$} & \multirow[t]{2}{*}{ Volunteer intervention } & \multirow[t]{2}{*}{ Co-interventions } & \multirow[t]{2}{*}{ Control group } & \multirow{2}{*}{$\begin{array}{l}\text { Outcome measures and } \\
\text { how assessed }\end{array}$} & \multirow[t]{2}{*}{ Outcomes } & \multicolumn{2}{|c|}{ Quality Assessment } \\
\hline & & & & & & & & Risk of bias & Total \\
\hline $\begin{array}{l}\text { Brown \& } \\
\text { Jones, } \\
\text { 2009[46] }\end{array}$ & Pilot project & $\begin{array}{l}\text { Acute hospital, } \\
\text { UK } \\
\text { Frail older } \\
\text { patients from } 2 \\
\text { wards }\end{array}$ & $\begin{array}{l}6 \text { volunteers, recruited by } \\
\text { voluntary services team } \\
\text { and trained by speech and } \\
\text { language team, providing } \\
\text { mealtime assistance }\end{array}$ & $\begin{array}{l}\text { Annual audit of } \\
\text { nutritional } \\
\text { screening } \\
\text { Additional staff } \\
\text { training } \\
\text { Nutrition } \\
\text { awareness week } \\
\text { Update of } \\
\text { screening tool, } \\
\text { care pathways } \\
\text { and referral forms } \\
\text { to dieticians }\end{array}$ & None & $\begin{array}{l}\text { - Rate of nutritional } \\
\text { screening: annual audit } \\
\text { - Informal feedback } \\
\text { from staff }\end{array}$ & $\begin{array}{l}\text { - No difference in nutritional } \\
\text { screening } \\
\text { - Decreased number of patients at } \\
\text { high or medium risk of } \\
\text { malnutrition in annual audit } \\
\text { - Reports that food intake } \\
\text { improved in reluctant eaters } \\
\text { - Reports that nurses felt more } \\
\text { supported to provide mealtime } \\
\text { care. } \\
\text { - Reports that nurses had greater } \\
\text { awareness of nutritional care }\end{array}$ & Not scored & \\
\hline $\begin{array}{l}\text { Buys et } \\
\text { al, } 2013\end{array}$ & $\begin{array}{l}\text { Observational } \\
\text { programme } \\
\text { evaluation }\end{array}$ & $\begin{array}{l}\text { Acute hospital, } \\
\text { USA } \\
\text { Patients over } 65 \\
\text { years of age on } \\
\text { the Acute Care } \\
\text { of Elders Unit }\end{array}$ & $\begin{array}{l}\text { Volunteers, recruited } \\
\text { from pool of existing } \\
\text { hospital volunteers and } \\
\text { trained by registered } \\
\text { nurse, providing mealtime } \\
\text { assistance }\end{array}$ & None & None & $\begin{array}{l}\text { - Volunteer activity: } \\
\text { analysis of encounter } \\
\text { forms } \\
\text { - Staff costs saved: time } \\
\text { spent by volunteers and } \\
\text { equivalent staff cost }\end{array}$ & $\begin{array}{l}\text { - Volunteers performed an } \\
\text { average of } 3 \text { tasks per patient. } \\
\text { - Mean time of } 47.8 \text { minutes } \\
\text { spent with each patient with cost } \\
\text { saving of } \$ 11.94-\$ 26 \text { per } \\
\text { encounter }\end{array}$ & $4 / 7$ & $12 / 31$ \\
\hline $\begin{array}{l}\text { Gilbert et } \\
\text { al, } \\
\text { 2013[41] }\end{array}$ & $\begin{array}{l}\text { Cross- } \\
\text { sectional } \\
\text { observational } \\
\text { study }\end{array}$ & $\begin{array}{l}\text { Acute hospital, } \\
\text { UK } \\
191 \text { patients } \\
\text { from } 6 \text { medical } \\
\text { wards; mean } \\
\text { age } 85 \text { years }\end{array}$ & $\begin{array}{l}95 \text { volunteers, recruited } \\
\text { from local sixth form } \\
\text { colleges and trained by } \\
\text { speech and language } \\
\text { therapists, providing } \\
\text { mealtime assistance }\end{array}$ & None & $\begin{array}{l}87 \text { patients from } \\
\text { the same wards } \\
\text { receiving usual } \\
\text { care }\end{array}$ & $\begin{array}{l}\text { - Food and drink intake: } \\
\text { estimated \% of meal } \\
\text { eaten } \\
\text { - Patient enjoyment of } \\
\text { meal: questionnaire }\end{array}$ & $\begin{array}{l}\text { - Significant increase in food and } \\
\text { drink intake, } p<0.01 \text { (raw data } \\
\text { not presented) } \\
\text { - Significant increase in enjoyment } \\
\text { of meals, } p<0.001 \text { (raw data not } \\
\text { presented) }\end{array}$ & Not scored & \\
\hline $\begin{array}{l}\text { Huang et } \\
\text { al, } \\
\text { 2015[42] }\end{array}$ & Pilot study & $\begin{array}{l}\text { Acute hospital, } \\
\text { Australia } \\
8 \text { malnourished } \\
\text { patients from } 2 \\
\text { aged care } \\
\text { wards; mean } \\
\text { age } 83 \text { years }\end{array}$ & $\begin{array}{l}5 \text { volunteers, trained by } \\
\text { dietician, speech and } \\
\text { language therapist and } \\
\text { nurses, providing } \\
\text { mealtime assistance }\end{array}$ & None & $\begin{array}{l}\text { Same participants } \\
\text { on days without } \\
\text { volunteers }\end{array}$ & $\begin{array}{l}\text { - Dietary intake: visual } \\
\text { estimate of food items to } \\
\text { nearest } 10 \% \\
\text { - Nurse and volunteer } \\
\text { opinions: questionnaire }\end{array}$ & $\begin{array}{l}\text { - Non-significant trend towards } \\
\text { increased protein and energy } \\
\text { intake with volunteers } \\
\text { - Positive feedback from nurses } \\
\text { and volunteers, programme felt to } \\
\text { be helpful }\end{array}$ & $4 / 7$ & $18 / 31$ \\
\hline
\end{tabular}




\begin{tabular}{|c|c|c|c|c|c|c|c|c|c|}
\hline \multirow[t]{2}{*}{ Study } & \multirow[t]{2}{*}{ Design } & \multirow{2}{*}{$\begin{array}{l}\text { Population \& } \\
\text { Setting }\end{array}$} & \multirow[t]{2}{*}{ Volunteer intervention } & \multirow[t]{2}{*}{ Co-interventions } & \multirow[t]{2}{*}{ Control group } & \multirow{2}{*}{$\begin{array}{l}\text { Outcome measures and } \\
\text { how assessed }\end{array}$} & \multirow[t]{2}{*}{ Outcomes } & \multicolumn{2}{|c|}{ Quality Assessmen } \\
\hline & & & & & & & & Risk of bias & Total \\
\hline $\begin{array}{l}\text { Huxtable } \\
\& \\
\text { Palmer, } \\
\text { 2013[32] }\end{array}$ & $\begin{array}{l}\text { Quasi- } \\
\text { experimental } \\
\text { observational } \\
\text { study }\end{array}$ & $\begin{array}{l}\text { Acute hospital, } \\
\text { Australia } \\
1012 \text { patients } \\
\text { on } 6 \text { adult } \\
\text { wards; mean } \\
\text { age } 65 \text { years. }\end{array}$ & $\begin{array}{l}\text { Volunteers providing } \\
\text { mealtime assistance }\end{array}$ & $\begin{array}{l}\text { Protected } \\
\text { mealtimes: main } \\
\text { focus of study }\end{array}$ & $\begin{array}{l}\text { Demographically } \\
\text { similar cohort } \\
\text { from the same } \\
\text { wards prior to the } \\
\text { introduction of } \\
\text { the intervention. }\end{array}$ & $\begin{array}{l}\text { - Energy and protein } \\
\text { intake: estimated } \\
\text { proportion of meal } \\
\text { consumed } \\
\text { - Assistance provided: } \\
\text { observed }\end{array}$ & $\begin{array}{l}\text { - Increase in protein intake at } \\
\text { breakfast of } 2 \mathrm{~g}(\mathrm{p}=0.025) \\
\text { - No change in energy or protein } \\
\text { intake at lunch, dinner or over } 24 \\
\text { hours } \\
\text { - Twice as many patients fed post } \\
\text { intervention ( } 15 \% \text { vs } 29 \% \mathrm{p}= \\
0.002 \text { ) } \\
\text { - Mean time until assistance } \\
\text { provided reduced from } 5 \text { minutes } \\
\text { to } 1 \text { minute at dinnertime } \\
\text { - Increase in amount of meals } \\
\text { within reach ( } p=0.000) \text {. } \\
\text { - Increase in time provided to eat } \\
\text { meals ( } p=0.000) \text {. } \\
\text { - Increased number of patients } \\
\text { positioned appropriately prior to } \\
\text { meal ( } p=0.015) \\
\text { - Mealtime interruptions } \\
\text { increased ( } p=0.000)\end{array}$ & $4 / 7$ & $20 / 31$ \\
\hline $\begin{array}{l}\text { Manning } \\
\text { et al, } \\
\text { 2012[43] }\end{array}$ & $\begin{array}{l}\text { Cross- } \\
\text { sectional } \\
\text { mixed } \\
\text { methods } \\
\text { study }\end{array}$ & $\begin{array}{l}\text { Acute hospital, } \\
\text { Australia } \\
\text { Convenience } \\
\text { sample of } 23 \\
\text { patients from } 2 \\
\text { wards; mean } \\
\text { age } 83.2 \text { years }\end{array}$ & $\begin{array}{l}\text { Volunteers, trained by } \\
\text { programme staff, } \\
\text { providing mealtime } \\
\text { assistance }\end{array}$ & None & $\begin{array}{l}\text { Same participants } \\
\text { on days without } \\
\text { volunteers }\end{array}$ & $\begin{array}{l}\text { - Energy and protein } \\
\text { intake: food waste } \\
\text { weighed } \\
\text { - Time spent assisting: } \\
\text { observed } \\
\text { - Patient opinion on } \\
\text { programme: informal } \\
\text { patient interviews } \\
\text { - Nursing and volunteer } \\
\text { opinion: questionnaires }\end{array}$ & $\begin{array}{l}\text { - Intake increased by } 396 \mathrm{~kJ}(\mathrm{p}= \\
0.005) \text { and } 4.3 \mathrm{~g} \text { protein }(\mathrm{p}=0.009) \\
\text { at lunchtime and by } 448 \mathrm{~kJ}(\mathrm{p}= \\
0.113) \text { and } 8.7 \mathrm{~g} \text { protein }(\mathrm{p}=0.004) \\
\text { over } 24 \text { hours } \\
\text { - Volunteers assisted by a mean of } \\
12.3 \text { minutes, nurses by } 6.0 \\
\text { minutes } \\
\text { - Positive feedback from patients } \\
\text { and nurses on volunteer presence. } \\
\text { - Nurses considered volunteers } \\
\text { effective, helpful, essential }\end{array}$ & $4 / 7$ & $19 / 31$ \\
\hline $\begin{array}{l}\text { Murray, } \\
2006[47]\end{array}$ & $\begin{array}{l}\text { Service } \\
\text { development } \\
\text { project }\end{array}$ & $\begin{array}{l}\text { Acute hospital, } \\
\text { UK } \\
\text { Patients from } \\
\text { admissions } \\
\text { ward and } 4 \text { sub- } \\
\text { acute wards for } \\
\text { older people }\end{array}$ & $\begin{array}{l}\text { Volunteers, recruited by } \\
\text { voluntary services and } \\
\text { trained by programme } \\
\text { nurse, providing mealtime } \\
\text { assistance }\end{array}$ & $\begin{array}{l}\text { Protected } \\
\text { mealtimes } \\
\text { Extra snacks } \\
\text { available to all } \\
\text { patients }\end{array}$ & None & $\begin{array}{l}\text { - Barriers to intake: } \\
\text { multidisciplinary team } \\
\text { discussion } \\
\text { - Informal feedback on } \\
\text { programme }\end{array}$ & $\begin{array}{l}\text { - Barriers reported prior to } \\
\text { implementation: lack of time and } \\
\text { staff, not enough cutlery, } \\
\text { workload, staff breaks, } \\
\text { interruptions } \\
\text { - Positive informal feedback from } \\
\text { patients and staff } \\
\text { - Anecdotally mealtimes a greater } \\
\text { priority and social aspects become } \\
\text { more important }\end{array}$ & Not scored & \\
\hline
\end{tabular}




\begin{tabular}{|c|c|c|c|c|c|c|c|c|c|}
\hline \multirow{2}{*}{ Study } & \multirow{2}{*}{ Design } & \multirow{2}{*}{$\begin{array}{l}\text { Population \& } \\
\text { Setting }\end{array}$} & \multirow{2}{*}{ Volunteer intervention } & \multirow[t]{2}{*}{ Co-interventions } & \multirow{2}{*}{ Control group } & \multirow{2}{*}{$\begin{array}{l}\text { Outcome measures and } \\
\text { how assessed }\end{array}$} & \multirow{2}{*}{ Outcomes } & \multicolumn{2}{|c|}{ Quality Assessmen } \\
\hline & & & & & & & & Risk of bias & Total \\
\hline $\begin{array}{l}\text { Roberts } \\
\text { et al, } \\
\text { 2014[44] }\end{array}$ & $\begin{array}{l}\text { Quasi } \\
\text { experimental } \\
\text { with before } \\
\text { and after } \\
\text { comparison } \\
\text { and } \\
\text { qualitative } \\
\text { study }\end{array}$ & $\begin{array}{l}\text { Acute hospital, } \\
\text { UK } \\
3911 \text { female } \\
\text { patients on one } \\
\text { acute elderly } \\
\text { ward }\end{array}$ & $\begin{array}{l}29 \text { volunteers, recruited } \\
\text { via voluntary services } \\
\text { department and trained } \\
\text { by dietician and speech } \\
\text { and language therapists, } \\
\text { providing mealtime } \\
\text { assistance }\end{array}$ & None & $\begin{array}{l}\text { Cohort of patients } \\
\text { on the same ward } \\
\text { pre-intervention, } \\
\text { as well as } \\
\text { contemporaneous } \\
\text { control ward with } \\
\text { comparable } \\
\text { elderly female } \\
\text { inpatients }\end{array}$ & $\begin{array}{l}\text { - Feasibility of recruiting } \\
\text { and training volunteers: } \\
\text { number of volunteers } \\
\text { recruited and trained } \\
\text { - Acceptability of } \\
\text { volunteers: semi- } \\
\text { structure interviews with } \\
\text { patients, relatives, staff } \\
\text { and volunteers }\end{array}$ & $\begin{array}{l}\text { - Feasible to recruit and train } \\
\text { volunteers in the role; } 59 \\
\text { volunteers identified, } 29 \text { trained } \\
\text { - Positive impact of volunteers } \\
\text { agreed by patients, relatives, staff } \\
\text { and nurses. Quality of mealtime } \\
\text { care improved }\end{array}$ & $5 / 7$ & $15 / 31$ \\
\hline $\begin{array}{l}\text { Robinson } \\
\text { et al, } \\
\text { 2002[48] }\end{array}$ & Pilot study & $\begin{array}{l}\text { Acute hospital, } \\
\text { US } \\
34 \text { patients over } \\
\text { the age of } 65 \\
\text { years; mean } \\
\text { age } 78.2 \text { years }\end{array}$ & $\begin{array}{l}19 \text { volunteers (15 } \\
\text { students), recruited via } \\
\text { local press and trained by } \\
\text { a range of health } \\
\text { professionals, providing } \\
\text { mealtime assistance }\end{array}$ & None & $\begin{array}{l}34 \text { patients } \\
\text { matched on age, } \\
\text { assistance } \\
\text { required, reasons } \\
\text { for needing help }\end{array}$ & $\begin{array}{l}\text { - Food intake: estimated } \\
\text { percentage of meal } \\
\text { consumed } \\
\text { - Volunteer experiences: } \\
\text { recorded on encounter } \\
\text { forms }\end{array}$ & $\begin{array}{l}-59 \% \text { of meal eaten with } \\
\text { volunteers, 33\% eaten with nurses } \\
(p<0.001) \\
\text { - Volunteers enjoyed experience } \\
\text { and felt they were a positive } \\
\text { influence } \\
\text { - Nurses enthusiastic about } \\
\text { volunteers }\end{array}$ & $4 / 7$ & $15 / 31$ \\
\hline $\begin{array}{l}\text { Sneddon } \\
\text { \& Best, } \\
\text { 2011[45] }\end{array}$ & $\begin{array}{l}\text { Quality } \\
\text { improvement } \\
\text { project }\end{array}$ & $\begin{array}{l}\text { Acute hospital, } \\
\text { UK } \\
\text { Patients on } \\
\text { eight medical } \\
\text { wards and two } \\
\text { rehabilitation } \\
\text { wards }\end{array}$ & $\begin{array}{l}35 \text { volunteers, recruited } \\
\text { by voluntary services } \\
\text { manager and trained by a } \\
\text { variety of health } \\
\text { professionals, providing } \\
\text { mealtime assistance }\end{array}$ & None & None & $\begin{array}{l}\text { - Volunteer opinion of } \\
\text { programme: informal } \\
\text { feedback } \\
\text { - Nursing opinion of } \\
\text { programme: formal and } \\
\text { informal feedback } \\
\text { - Patient experience: } \\
\text { informal feedback }\end{array}$ & $\begin{array}{l}\text { - Volunteers enjoy their role and } \\
\text { feel useful } \\
\text { - Reports that patients receive } \\
\text { meals and assistance more quickly } \\
\text { - Mealtimes a more sociable event } \\
\text { - Patients enjoyed talking with the } \\
\text { volunteers and being assisted by } \\
\text { them }\end{array}$ & Not scored & \\
\hline $\begin{array}{l}\text { Walton } \\
\text { et al, } \\
\text { 2008[49] }\end{array}$ & Pilot study & $\begin{array}{l}\text { Acute hospital, } \\
\text { Australia } \\
\text { Convenience } \\
\text { sample of } 9 \\
\text { patients from } \\
\text { an aged care } \\
\text { ward; mean age } \\
89 \text { years }\end{array}$ & $\begin{array}{l}25 \text { volunteers, trained by } \\
\text { programme staff, } \\
\text { providing mealtime } \\
\text { assistance }\end{array}$ & None & $\begin{array}{l}\text { Same participants } \\
\text { on days without } \\
\text { volunteers }\end{array}$ & $\begin{array}{l}\text { - Energy and protein } \\
\text { intake: waste food } \\
\text { weighed. } \\
\text { - Nurse and volunteer } \\
\text { opinion of the } \\
\text { programme: } \\
\text { questionnaires and focus } \\
\text { group with volunteers. }\end{array}$ & $\begin{array}{l}\text { - Increase in protein }(10.1 \mathrm{~g}, \mathrm{p}= \\
0.015) \text { and energy }(105 \mathrm{kcal}, \mathrm{p}= \\
0.072) \text { intake at lunchtimes and } \\
\text { over } 24 \text { hours (protein } 10.7 \mathrm{~g}, \mathrm{p}= \\
0.015 \text {, energy } 56 \mathrm{kcal}, \mathrm{p}=0.509) \\
\text { - All nurses }(\mathrm{n}=13) \text { felt volunteers } \\
\text { were valuable } \\
\text { - Most volunteers }(12 / 14) \text { felt } \\
\text { company at mealtimes positively } \\
\text { influenced dietary intake }\end{array}$ & $4 / 7$ & $15 / 31$ \\
\hline $\begin{array}{l}\text { Wong et } \\
\text { al, } \\
\text { 2008[51] }\end{array}$ & $\begin{array}{l}\text { Quasi } \\
\text { experimental } \\
\text { observational } \\
\text { study }\end{array}$ & $\begin{array}{l}\text { Dementia } \\
\text { assessment } \\
\text { unit, NZ } \\
7 \text { patients; } \\
\text { mean age } 77 \\
\text { years }\end{array}$ & $\begin{array}{l}\text { Volunteers providing } \\
\text { mealtime assistance to } \\
\text { one patient }\end{array}$ & $\begin{array}{l}\text { None at same } \\
\text { time as volunteers } \\
\text { introduced }\end{array}$ & $\begin{array}{l}\text { Same participants } \\
\text { prior to } \\
\text { introduction of } \\
\text { volunteers }\end{array}$ & $\begin{array}{l}\text { - Energy and protein } \\
\text { intake: estimated } \\
\text { proportion of meal } \\
\text { consumed } \\
\text { - Nutritional status: } \\
\text { weight, BMI and MNA }\end{array}$ & $\begin{array}{l}\text { - Increase of } 44.1 \mathrm{kcal} \text { per patient } \\
\text { at lunchtime }(p<0.001) \\
\text { - BMI increased by } 0.37(p<0.04) \\
\text { and mid arm circumference by } \\
0.14 \mathrm{~cm} \text { (non-significant) }\end{array}$ & $4 / 7$ & $18 / 31$ \\
\hline
\end{tabular}




\begin{tabular}{|c|c|c|c|c|c|c|c|c|c|}
\hline \multirow[t]{2}{*}{ Study } & \multirow[t]{2}{*}{ Design } & \multirow{2}{*}{$\begin{array}{l}\text { Population \& } \\
\text { Setting }\end{array}$} & \multirow[t]{2}{*}{ Volunteer intervention } & \multirow[t]{2}{*}{ Co-interventions } & \multirow[t]{2}{*}{ Control group } & \multirow{2}{*}{$\begin{array}{l}\text { Outcome measures and } \\
\text { how assessed }\end{array}$} & \multirow[t]{2}{*}{ Outcomes } & \multicolumn{2}{|c|}{ Quality Assessmen } \\
\hline & & & & & & & & Risk of bias & Total \\
\hline $\begin{array}{l}\text { Wright et } \\
\text { al, } \\
\text { 2008[50] }\end{array}$ & $\begin{array}{l}\text { Prospective } \\
\text { observational } \\
\text { study with } \\
\text { retrospective } \\
\text { control }\end{array}$ & $\begin{array}{l}\text { Acute hospital, } \\
\text { UK } \\
16 \text { patients over } \\
65 \text { years } \\
\text { prescribed a } \\
\text { modified diet or } \\
\text { thickened fluids } \\
\text { Mean age } 76 \\
\text { years }\end{array}$ & $\begin{array}{l}3 \text { volunteers (nutrition } \\
\text { students), trained by } \\
\text { dietician and speech and } \\
\text { language therapists, } \\
\text { present } 8 \text { hours a day for } \\
\text { three days per week. } \\
\text { Role included mealtime } \\
\text { assistance, help with } \\
\text { menu choices, distributing } \\
\text { snacks and supplements, } \\
\text { attending nursing } \\
\text { handovers, close contact } \\
\text { with dieticians and speech } \\
\text { and language therapists }\end{array}$ & $\begin{array}{l}\text { Individualised } \\
\text { eating and } \\
\text { drinking plan }\end{array}$ & $\begin{array}{l}\text { Historical control } \\
\text { group: } 30 \text { patients } \\
\text { over } 60 \text { years } \\
\text { eating a modified } \\
\text { texture diet. } \\
\text { Differences in } \\
\text { assistance } \\
\text { required and diet } \\
\text { prescribed } \\
\text { compared with } \\
\text { intervention } \\
\text { group. }\end{array}$ & $\begin{array}{l}\text { - Energy and protein } \\
\text { intake: food record } \\
\text { charts completed by } \\
\text { volunteers }\end{array}$ & $\begin{array}{l}\text { - Increase in energy intake from } \\
1180 \mathrm{kcal} \text { to } 1798 \mathrm{kcal}(\mathrm{p}<0.001) \\
\text { - Increase in protein intake from } \\
25 \mathrm{~g} \text { to } 53 \mathrm{~g}(\mathrm{p}=0.01) \\
\text { - Increase in median energy and } \\
\text { protein intake derived from oral } \\
\text { nutritional supplements: from } 0 \text { to } \\
1204 \mathrm{kcal}(\mathrm{p}<0.0002) \text { and from } 0 \text { to } \\
15 \mathrm{~g}(\mathrm{p}<0.001)\end{array}$ & $5 / 7$ & $20 / 31$ \\
\hline $\begin{array}{l}\text { Anonym } \\
\text { ous, } \\
\text { 2012[39] }\end{array}$ & $\begin{array}{l}\text { Service } \\
\text { development } \\
\text { project }\end{array}$ & $\begin{array}{l}\text { Acute hospital, } \\
\text { UK }\end{array}$ & $\begin{array}{l}12 \text { volunteers providing } \\
\text { help with pre-meal } \\
\text { preparation and } \\
\text { socialisation but not } \\
\text { feeding patients }\end{array}$ & None & None & $\begin{array}{l}\text { - Volunteer and nursing } \\
\text { opinion: informal } \\
\text { comment }\end{array}$ & $\begin{array}{l}\text { - Volunteers provide extra support } \\
\text { to nurses }\end{array}$ & Not scored & \\
\hline
\end{tabular}

$\%$ = percentage; $\mathrm{g}$ = grams; $\mathrm{kcal}$ = kilocalories; $\mathrm{kJ}=$ kilojoules; $\mathrm{BMI}=$ body mass index; $\mathrm{MNA}=$ Mini Nutritional Assessment; $\mathrm{cm}=$ centimetres 
Table 3: Protein and Energy Intake Following Introduction of Volunteers

\begin{tabular}{|c|c|c|c|c|c|c|c|}
\hline & \multirow{2}{*}{ Participants } & \multirow{2}{*}{ Control Group } & \multirow{2}{*}{$\begin{array}{c}\text { Method of } \\
\text { Calculating Intake }\end{array}$} & \multicolumn{2}{|c|}{ Change in Protein Intake } & \multicolumn{2}{|c|}{ Change in Energy Intake } \\
\hline & & & & Single Meal & Daytime & Single Meal & Daytime \\
\hline $\begin{array}{l}\text { Huang et } \\
\text { al[42] }\end{array}$ & $\begin{array}{l}\text { Targeted population, } \\
n=8\end{array}$ & $\begin{array}{c}\text { Same participants on } \\
\text { days without } \\
\text { volunteers }\end{array}$ & Visual estimate & $\begin{array}{l}+3.1 \mathrm{~g} \\
\mathrm{NS}\end{array}$ & $\begin{array}{l}+0.8 g \\
\quad N S\end{array}$ & $\begin{array}{l}+76 \mathrm{kcal} \\
\mathrm{NS}\end{array}$ & $\begin{array}{c}+59 \mathrm{kcal} \\
\mathrm{NS}\end{array}$ \\
\hline $\begin{array}{l}\text { Huxtable \& } \\
\text { Palmer[32] }\end{array}$ & $\begin{array}{c}\text { Total ward } \\
\text { population, } n=1012\end{array}$ & $\begin{array}{l}\text { Pre intervention } \\
\text { cohort }\end{array}$ & Visual estimate & $\begin{array}{l}+2 \mathrm{~g} \text { at } \\
\text { breakfast } \\
\mathrm{p}=0.025\end{array}$ & No difference & No difference & No difference \\
\hline $\begin{array}{l}\text { Manning et } \\
\text { al[43] }\end{array}$ & $\begin{array}{l}\text { Targeted population, } \\
\qquad \mathrm{n}=23\end{array}$ & $\begin{array}{c}\text { Same participants on } \\
\text { days without } \\
\text { volunteers }\end{array}$ & Weighed & $\begin{array}{c}+4.3 g \\
p=0.009\end{array}$ & $\begin{array}{c}+8.7 g \\
p=0.004\end{array}$ & $\begin{array}{l}+95 \mathrm{kcal}^{*} \\
\mathrm{p}=0.005\end{array}$ & $\begin{array}{c}+107 \mathrm{kcal}^{*} \\
\text { NS }\end{array}$ \\
\hline $\begin{array}{l}\text { Walton et } \\
\text { al[49] }\end{array}$ & $\begin{array}{l}\text { Targeted population, } \\
\qquad n=9\end{array}$ & $\begin{array}{c}\text { Same participants on } \\
\text { days without } \\
\text { volunteers }\end{array}$ & Weighed & $\begin{array}{c}+10.1 g \\
p=0.015\end{array}$ & $\begin{array}{c}+10.7 g \\
p=0.015\end{array}$ & $\begin{array}{l}+105 \mathrm{kcal} \\
\mathrm{p}=0.072\end{array}$ & $\begin{array}{l}+56 \mathrm{kcal} \\
\mathrm{NS}\end{array}$ \\
\hline Wong et al[51] & $\begin{array}{l}\text { Targeted population, } \\
\qquad n=7\end{array}$ & $\begin{array}{c}\text { Same participants on } \\
\text { days without } \\
\text { volunteers }\end{array}$ & Visual estimate & Not re & orted & $\begin{array}{l}+44.1 \mathrm{kcal} \\
\mathrm{p}<0.001\end{array}$ & Not reported \\
\hline $\begin{array}{l}\text { Wright et } \\
\text { al[50] }\end{array}$ & $\begin{array}{l}\text { Targeted population, } \\
\qquad \mathrm{n}=16\end{array}$ & $\begin{array}{l}\text { Historical group, } \mathrm{n}= \\
30\end{array}$ & Food charts & Not reported & $\begin{array}{l}+28 g^{* *} \\
p=0.01\end{array}$ & Not reported & $\begin{array}{c}+618 \mathrm{kcal}^{* *} \\
\mathrm{p}<0.001\end{array}$ \\
\hline
\end{tabular}

$\mathrm{N}=$ number; $\mathrm{g}=$ grams; $\mathrm{NS}=$ not significant; kcal = kilocalories; *reported in original paper as kilojoules but converted to kilocalories to aid comparability in this analysis; $* *$ intake from $8 \mathrm{am}$ to $4 \mathrm{pm}$ when volunteers were present 


\section{References}

1. Russell C, Elia M (2012) Nutrition Screening Survey in the UK and Republic of Ireland in 2011. BAPEN, Redditch

2. Elia M (2003) The "MUST" Report. Nutritional screening of adults: a multidisciplinary responsibility. Development and use of the "Malnutrition Universal Screening Tool" ('MUST') for adults. BAPEN, Redditch

3. Kaiser MJ, Bauer JM, Rämsch C, Uter W, Guigoz Y, Cederholm T, Thomas DR, Anthony PS, Charlton KE, Maggio M, Tsai AC, Vellas B, Sieber CC (2010) Frequency of malnutrition in older adults: a multinational perspective using the mini nutritional assessment. J Am Geriatr Soc 58:1734-8. doi: 10.1111/j.1532-5415.2010.03016.x

4. Guest JF, Panca M, Baeyens J-P, de Man F, Ljungqvist O, Pichard C, Wait S, Wilson L (2011) Health economic impact of managing patients following a community-based diagnosis of malnutrition in the UK. Clin Nutr 30:422-9.

5. Isabel M, Correia T, Waitzberg D (2003) The impact of malnutrition on morbidity, mortality, length of hospital stay and costs evaluated through a multivariate model analysis. Clin Nutr 22:235-239.

6. Edington J, Boorman J, Durrant ER, Perkins A, Giffin C V, James R, Thomson JM, Oldroyd JC, Smith JC, Torrance a D, Blackshaw V, Green S, Hill CJ, Berry C, McKenzie C, Vicca N, Ward JE, Coles SJ (2000) Prevalence of malnutrition on admission to four hospitals in England. The Malnutrition Prevalence Group. Clin Nutr 19:191-5.

7. Chima C, Barco K, Dewitt M, Maeda M, Teran J, Mullen K (1997) Relationship of nutritional status to length of stay, hospital costs, and discharge status of patients hospitalized in the medicine service. J Am Diet Assoc 97:975-8.

8. Banks M, Bauer J, Graves N, Ash S (2010) Malnutrition and pressure ulcer risk in adults in Australian health care facilities. Nutrition 26:896-901.

9. Lumbers M, Driver LT, Howland RJ, Older MW, Williams CM (1996) Nutritional status and clinical outcome in elderly female surgical orthopaedic patients. Clin Nutr 15:101-7.

10. Neumann S, Miller M, Daniels L, Crotty M (2005) Nutritional status and clinical outcomes of older patients in rehabilitation. J Hum Nutr Diet 18:129-36.

11. Friedmann JM, Jensen GL, Smiciklas-Wright H, McCamish M (1997) Predicting early nonelective hospital readmission in nutritionally compromised older adults. Am J Clin Nutr 65:1714-20.

12. Kagansky N, Berner Y, Koren-Morag N, Perelman L, Knobler H, Levy S (2005) Poor nutritional habits are predictors of poor outcome in very old hospitalized patients. Am J Clin Nutr 82:784-791.

13. Liu L, Bopp MM, Roberson PK, Sullivan DH (2002) Undernutrition and risk of mortality in elderly patients within 1 year of hospital discharge. J Gerontol A Biol Sci Med Sci 57:M741-6.

14. Sullivan DH, Walls RC (1998) Protein-Energy Undernutrition and the Risk of Mortality Within Six Years of Hospital Discharge. J Am Coll Nutr 17:571-578.

15. Elia M (2015) The cost of malnutrition in England and potential cost savings from nutritional interventions. BAPEN, Redditch

16. Milne A, Potter J, Vivanti A, Avenell A (2009) Protein and energy supplementation in elderly people at risk from malnutrition. Cochrane Database Syst Rev 2:Art. No.: CD003288.

17. Johansen N, Kondrup J, Plum LM, Bak L, Nørregaard P, Bunch E, Baernthsen H, Andersen JR, Larsen IH, Martinsen A (2004) Effect of nutritional support on clinical outcome in 
patients at nutritional risk. Clin Nutr 23:539-50.

18. Rüfenacht U, Rühlin M, Wegmann M, Imoberdorf R, Ballmer PE (2010) Nutritional counseling improves quality of life and nutrient intake in hospitalized undernourished patients. Nutrition 26:53-60.

19. Starke J, Schneider H, Alteheld B, Stehle P, Meier R (2011) Short-term individual nutritional care as part of routine clinical setting improves outcome and quality of life in malnourished medical patients. Clin Nutr 30:194-201.

20. Feldblum I, German L, Castel H, Harman-Boehm I, Shahar DR (2011) Individualized nutritional intervention during and after hospitalization: the nutrition intervention study clinical trial. J Am Geriatr Soc 59:10-7.

21. Barton A, Beigg C, Macdonald I, Allison S (2000) A recipe for improving food intakes in elderly hospitalized patients. Clin Nutr 19:451-4.

22. Gall MJ, Grimble GK, Reeve NJ, Thomas SJ (1998) Effect of providing fortified meals and between-meal snacks on energy and protein intake of hospital patients. Clin Nutr 17:259-64.

23. Olin A, Osterberg P, Hadell K, Armyr I, Jerstrom S, Ljungqvist O (1996) Energy-enriched hospital food to improve energy intake in elderly patients. J Parenter Enter Nutr 20:9397.

24. Xia C, McCutcheon H (2006) Mealtimes in hospital--who does what? J Clin Nurs 15:12217.

25. Naithani S, Whelan K, Thomas J, Gulliford MC, Morgan M (2008) Hospital inpatients' experiences of access to food: a qualitative interview and observational study. Health Expect 11:294-303.

26. Naithani S, Thomas JE, Whelan K, Morgan M, Gulliford MC (2009) Experiences of food access in hospital. A new questionnaire measure. Clin Nutr 28:625-30.

27. Tsang $M$ (2008) Is there adequate feeding assistance for the hospitalised elderly who are unable to feed themselves? Nutr Diet 65:222-228.

28. Kowanko I, Simon S, Wood J (1999) Nutritional care of the patient: nurses' knowledge and attitudes in an acute care setting. J Clin Nurs 8:217-24.

29. Ross LJ, Mudge AM, Young AM, Banks M (2011) Everyone's problem but nobody's job: Staff perceptions and explanations for poor nutritional intake in older medical patients. Nutr Diet 68:41-46.

30. Bradley L, Rees C (2003) Reducing nutritional risk in hospital: the red tray. Nurs Stand 17:33-37. doi: 10.7748/ns2003.03.17.26.33.c3357

31. Hickson M, Connolly A, Whelan K (2011) Impact of protected mealtimes on ward mealtime environment, patient experience and nutrient intake in hospitalised patients. J Hum Nutr Diet 24:370-4.

32. Huxtable S, Palmer M. (2013) The efficacy of protected mealtimes in reducing mealtime interruptions and improving mealtime assistance in adult inpatients in an Australian hospital. Eur J Clin Nutr 67:904-10.

33. Chan J, Carpenter C (2015) An Evaluation of a Pilot Protected Mealtime Program in a Canadian Hospital. Can J Diet Pract Res 76:81-85. doi: 10.3148/cjdpr-2014-035

34. Green SM, Martin HJ, Roberts HC, Sayer AA (2011) A systematic review of the use of volunteers to improve mealtime care of adult patients or residents in institutional settings. J Clin Nurs 20:1810-23. doi: 10.1111/j.1365-2702.2010.03624.x

35. Tassone EC, Tovey JA, Paciepnik JE, Keeton IM, Khoo AY, Van Veenendaal NG, Porter J (2015) Should we implement mealtime assistance in the hospital setting? A systematic 
literature review with meta-analyses. J Clin Nurs 24:2710-21. doi: 10.1111/jocn.12913

36. Moher D, Liberati A, Tetzlaff J, Altman DG (2009) Preferred reporting items for systematic reviews and meta-analyses: the PRISMA statement. BMJ 339:b2535. doi: 10.1136/bmj.b2535

37. Downs SH, Black N (1998) The feasibility of creating a checklist for the assessment of the methodological quality both of randomised and non-randomised studies of health care interventions. J Epidemiol Community Health 52:377-84.

38. Centre for Reviews and Dissemination (2009) Systematic Reviews: CRD's guidance for undertaking reviews in health care. doi: 10.1016/S1473-3099(10)70065-7

39. Anonymous (2012) Volunteers support staff in creating the right mealtime environment. Nurs Stand 26:22.

40. Buys DR, Flood KL, Real K, Chang M, Locher JL (2013) Mealtime assistance for hospitalized older adults: a report on the SPOONS volunteer program. J Gerontol Nurs 39:18-22.

41. Gilbert J, Appleton A, Jerrim J, Beard C, Russell-Jones D (2013) Assisted feeding for elderly inpatients. Clin Med J R Coll Physicians London 13:324.

42. Huang CS, Dutkowski K, Fuller A, Walton K (2015) Evaluation of a pilot volunteer feeding assistance program: Influences on the dietary intakes of elderly hospitalised patients and lessons learnt. J Nutr Health Aging 19:206-210. doi: 10.1007/s12603-014-0529-x

43. Manning F, Harris K, Duncan R, Walton K, Bracks J, Larby L, Vari L, Jukkola K, Bell J, Chan M, Batterham M (2012) Additional feeding assistance improves the energy and protein intakes of hospitalised elderly patients. A health services evaluation. Appetite 59:471-7.

44. Roberts HC, De Wet S, Porter K, Rood G, Diaper N, Robison J, Pilgrim L. A, Elia M, Jackson A. A, Cooper C, Sayer Aihie A, Robinson S (2014) The feasibility and acceptability of training volunteer mealtime assistants to help older acute hospital inpatients: the Southampton Mealtime Assistance Study. J Clin Nurs 23:3240-9. doi: 10.1111/jocn.12573

45. Sneddon J, Best C (2011) Introduction of mealtime volunteers in a district general hospital. Nurs Stand 26:37-41.

46. Brown H, Jones L (2009) The role of dining companions in supporting nursing care. Nurs Stand 23:40-6.

47. Murray C. (2006) Improving nutrition for older people. Nurs Older People 18:18-22.

48. Robinson S, Clump D, Weitzel T, Henderson L, Lee K, Schwartz C, Egizii P, Metz L (2002) The Memorial Meal Mates: A program to improve nutrition in hospitalized older adults. Geriatr Nurs 23:332-335.

49. Walton K, Williams P, Bracks J, Zhang Q, Pond L, Smoothy R, Tapsell L, Batterham M, Vari $\mathrm{L}$ (2008) A volunteer feeding assistance program can improve dietary intakes of elderly patients--a pilot study. Appetite 51:244-8.

50. Wright L, Cotter D, Hickson M (2008) The effectiveness of targeted feeding assistance to improve the nutritional intake of elderly dysphagic patients in hospital. J Hum Nutr Diet 21:555-62.

51. Wong A, Burford S, Wyles CL, Mundy H, Sainsbury R (2008) Evaluation of strategies to improve nutrition in people with dementia in an assessment unit. J Nutr Health Aging 12:309-12.

52. Naylor C, Mundle C, Weaks L, Buck D (2013) Volunteering in health and care. Securing a sustainable future. London: The King's Fund

53. Berrut G, Favreau AM, Dizo E, Tharreau B, Poupin C, Gueringuili M, Fressinaud P, Ritz P 
(2002) Estimation of calorie and protein intake in aged patients: validation of a method based on meal portions consumed. J Gerontol A Biol Sci Med Sci 57:M52-6.

54. Mudge AM, Ross LJ, Young AM, Isenring EA, Banks MD (2011) Helping understand nutritional gaps in the elderly (HUNGER): a prospective study of patient factors associated with inadequate nutritional intake in older medical inpatients. Clin Nutr 30:320-5. doi: 10.1016/j.clnu.2010.12.007

55. Wright L, Cotter D, Hickson M, Frost G (2005) Comparison of energy and protein intakes of older people consuming a texture modified diet with a normal hospital diet. J Hum Nutr Diet 18:213-9. doi: 10.1111/j.1365-277X.2005.00605.x

\section{Appendix 1: Medline Search Strategy}

\begin{tabular}{|l|l|}
\hline & $\begin{array}{l}\text { exp Meals/ or (feed* or eat* or food* or dine* or dining or breakfast* or dinner* or } \\
\text { lunch*or tea or teatime* or supper* or meal* or diet*).tw }\end{array}$ \\
\hline AND & Exp Volunteers/ or (assist* or help* or encourag*).tw \\
\hline AND & $\begin{array}{l}\text { Exp Inpatients/ or exp Hospital Units/ or exp Hospitals/ or (hospital* or in-patient* or } \\
\text { inpatient* or in-hospital*).tw }\end{array}$ \\
\hline AND & $\begin{array}{l}\text { Exp Nutrition Disorders/ or exp Nutritional Requirements/ or (nutri* or malnutri* or } \\
\text { malnourish* or undernutri* or under-nutri* or undernourish* or protein-energy } \\
\text { malnutrition).tw }\end{array}$ \\
\hline
\end{tabular}

